\title{
Improvisasi pembelajaran pendidikan Pancasila pada era pandemi Covid-19
}

\section{Kosasih Adi Saputra}

Universitas Siliwangi, Tasikmalaya, Indonesia

\section{INFORMASI ARTIKEL}

Sejarah Artikel:

Diterima: $2 / 2 / 2021$

Disetujui: $2 / 3 / 2021$

\author{
Kata kunci: \\ Improvisasi; \\ Pembelajaran Pendidikan \\ Pancasila; \\ Pandemi Covid 19
}

\section{Keywords:}

Improvisation;

Pancasila Education Learning;

The Covid pandemiv 19

\begin{abstract}
ABSTRAK
Pandemi Covid 19 sangat berdampak pada beberapa sektor penting salah satunya dalam bidang pendidikan. Pemerintah mengeluarkan berbagai regulasi agar pembelajaran tetap bisa dilaksanakan walaupun dalam jarak dan waktu yang terbatas. Sehingga para pendidik melakukan upaya untuk melukakan inovasi dan improvisasi pembelajaran. Pada mata kuliah Pendidikan Pancasila, dosen dituntut untuk tetap melakukan upaya pencapaian tujuan pembelajaran sebagai pembentukan karakter bangsa di tengah kondisi yang banyak mengalami hambatan. Artikel ini menyampaikan beberapa rumusan di antaranya: 1) bagaimana dampak pandemi covid terhadap pendidikan tinggi? 2) bagaimana dosen memberikan layanan pendidikan? 3) bagaimana ketercapaian tujuan pembelajaran pendidikan Pancasila? Penelitian ini melalui pendekatan deskriptif kualitatif, menitik beratkan pada pengalaman selama proses pembelajaran yang dilakukan dalam perkuliahan Pendidikan Pancasila ditambah dengan literatur hasil penelitian yang relevan. Penelitian dilaksanakan di Jurusan Gizi, Kesehatan Masyarakat, Akuntansi, serta Keuangan dan Perbankan. Semuanya di Universitas Siliwangi. Waktu penelitian dimulai dari Oktober 2020 sampai dengan Desember 2021. Hasil penelitian ini dapat disimpulkan bahwa Improvisasi Pembelajaran Pendidikan Pancasila pada Era Pandemi Covid-19 dilakukan melalui media pembelajaran dalam jaringan. Melakukan berbagai upaya peningkatan layanan pendidikan yang baik di antaranya dengan memilih media pembelajaran dapat mempermudah komunikasi dosen dengan mahasiswa, serta melakukan cara-cara yang kreatif dan inovatif selama proses pembelajaran online. Improvisasi bukan berarti mengabaikan esensi, karena dilakukan dengan persiapan yang baik, improvisasi yang dimaksud lebih kepada melihat situasi pada saat proses berlangsung sehingga dapat memperbaiki hal-hal yang menjadi kelemahan.
\end{abstract}

ABSTRACT
The Covid 19 pandemic affected several important sectors, one of which was in the field of
education. The government issued various regulations so that learning can still be carried out
even though it is within a limited distance and time. So that educators make efforts to innovate
and improvise learning. In the Pancasila Education course, lecturers are encouraged to continue
to make efforts to achieve the goal of spreading out as a national character building amidst many
obstacles. This article presents several formulas including: 1) what is the impact of the Covid
pandemic on higher education? 2) how do lecturers provide educational services? 3) how are
Pancasila education learning objectives achieved? This research uses a qualitative descriptive
approach, emphasizing the experience during the learning process carried out in Pancasila
Education courses coupled with relevant research literature. The research was conducted in the
Department of Nutrition, Public Health, Accounting, and Finance and Banking. All of them at
Siliwangi University. The research period starts from October 2020 to December 2021. The
results of this study can be concluded that the Improvisation of Pancasila Education in the Covid-
19 Pandemic Era was carried out through online learning media. Making various efforts to
improve good educational services, including by choosing learning media, can facilitate
communication between lecturers and students, as well as take creative and innovative ways
during the online learning process. Improvisation does not mean ignoring the essence, because it
is done with good preparation, the intended improvisation is more about seeing the situation
during the process so that it can fix things that become weaknesses.

\section{Pendahuluan}

Pendidikan tinggi merupakan jenjang sangat menentukan nasib generasi bangsa karena mencetak manusia secara profesional harus mampu menahan segala tantangan dunia yang sedang

Korespondensi: Kosasih Adi Saputra, kosasih.adisaputra@unsil.ac.id, Universitas Siliwangi,

Tasikmalaya, Indonesia

http://journal.uad.ac.id/index.php/citizenship 
terkena wabah yang sangat mematikan yakni virus corona atau covid 19. Pandemi Covid 19 sangat berdampak pada beberapa sektor penting salah satunya dalam bidang pendidikan. Pemerintah mengeluarkan berbagai regulasi agar pembelajaran tetap bisa dilaksanakan walaupun dalam jarak dan waktu yang terbatas. Sehingga para pendidik melakukan upaya untuk melukakan inovasi dan improvisasi pembelajaran.

Ketika pembelajaran dalam kondisi normal, di perguruan tinggi, dosen menyiapkan Rencana Pembelajaran Semester (RPS) dengan segalah perangkat dan setingan kelas. Kemudian menyiapkan pula model dan media pembelajaran yang lebih variatif yang dapat digunakan di ruangan. Namun, di masa pandemi ini, pembelajaran dilakukan secara daring, berbagai media online disiapkan dengan beragam pilihan aplikasi.

Menyikapi keadaan demikian di atas, pemerintah sendiri dalam hal ini Kementerian Pendidikan dan Kebudayaan (Kemendikbud) mengeluarkan regulasi dalam pendidikan dimasa darurat, kemudian dosen juga sebagai tenaga pendidik menyikapi aturan tersebut dengan melakukan berbagai upaya layanan pendidikan kepada mahasiswa dengan melakukan improvisasi dan inovasi pembelajaran. Selain itu, Mahasiswa sendiri tentunya bersiap diri dalam menekuni proses pembelajaran yang tidak biasa. Namun, dosen harus peka terhadap proses yang berjalan yakni dengan melakukan upaya koreksi dan evaluasi selama proses pembelajaran yang telah dilakukan. persepsi mahasiswa terhadap perkuliahan daring termasuk kategori tinggi, hal ini diharapkan dapat membantu mahasiswa dalam pelaksanaan proses perkuliahan di masa pandemi Covid-19, karena perkuliahan yang baik dan benar akan membantu mahasiswa dalam meningkatkan pemahaman dan keilmuan mahasiswa. Meskipun masih banyak mahasiswa yang di daerahnya belum mendapatkan jaringan internet yang memadai tetapi tidak menjadi mengurangi semangat mahasiswa untuk mengikuti perkuliahan daring (Lande, 2020; Sumarwoto, 2020)

Dalam kondisi apa pun, tujuan pembelajaran tentunya harus tercapai, dalam kondisi yang tak diharapkan seperti ini, bukan hal yang arif jika dosen membiarkan mahasiswa sebagai generasi muda tanpa perhatian dan pengawasan selama pembelajaran. Inti materi kuliah setiap pertemuan harus menjadi hal yang paling penting, disisi lain komunikasi secara virtual pun harus terjalin antara dosen dan mahasiswa sebagaimana tatap muka langsung. Dalam media virtual, zoom merupakan media yang paling banyak digunakan, namun jika itu tidak dilakukan dengan tempo waktu dan gaya belajar yang variatif mahasiswa akan jenuh dan tujuan pembelajaran akan sulit tercapai.

Mata kuliah Pendidikan Pancasila merupakan mata kuliah wajib berdasarkan amanat konstitusi. Lahirnya ketentuan dalam pasal 35 ayat (5) Undang-Undang Nomor 12 Tahun 2012 yang menyatakan bahwa kurikulum pendidikan tinggi wajib memuat mata kuliah pendidikan agama, pendidikan Pancasila, pendidikan kewarganegaraan, dan bahasa Indonesia, menunjukkan bahwa negara berkehendak agar pendidikan Pancasila dilaksanakan dan wajib dimuat dalam kurikulum perguruan tinggi sebagai mata kuliah yang berdiri sendiri. Dengan demikian, mata kuliah pendidikan Pancasila ini dapat lebih fokus dalam membina pemahaman dan penghayatan mahasiswa mengenai ideologi bangsa Indonesia. Artinya, pendidikan Pancasila diharapkan menjadi ruh dalam membentuk jati diri mahasiswa dalam mengembangkan jiwa profesionalitas mereka sesuai dengan bidang studi masing-masing. Selain itu, dengan mengacu kepada ketentuan pasal 2 Undang-Undang Nomor 12 Tahun 2012, sistem pendidikan tinggi di Indonesia harus berdasarkan Pancasila. Implikasinya, sistem pendidikan tinggi (baca: perguruan tinggi) di Indonesia harus terus mengembangkan nilai-nilai Pancasila dalam berbagai segi kebijakannya dan menyelenggarakan mata kuliah pendidikan Pancasila secara sungguh-sungguh dan bertanggung jawab.

Sebagai dosen yang mengampu Maka Kuliah Umum Wajib (MKWU) Pendidikan Pancasila yang dikhususkan bagi mahasiswa tingkat dasar yang baru pertama kali mengenal dunia Pendidikan Tinggi. Dosen mata kuliah umum harus berusaha keras membina mahasiswa yang bukan hana kemampuan intelektual namun juga keterampilan nilai, moral, sosial dan spiritual.

Proses pendidikan berujung pada satu tujuan yakni mencerdaskan kehidupan bangsa. Pelaksanaan pendidikan tidak lepas dari nilai-nilai Pancasila. Internalisasi nilai-nilai tersebut 
dilaksanakan dalam kegiatan pembelajaran. Pendidik berhak menentukan internalisasi nilai-nilai Pancasila pada setiap kegiatan tertentu dalam proses pembelajaran. Dengan demikian pembelajaran yang dilaksanakan secara daring pada masa pandemi ini tidak menutup kemungkinan siswa mengabaikan perwujudan setiap sila dalam diri dan lingkungannya. Dengan pembiasaan yang dilakukan secara terus-menerus dalam segala situasi pembelajaran diharapkan siswa bisa menjadi pribadi yang beriman dan bertakwa, serta cerdas menjadi warga negara yang menjunjung dan mengamalkan nilai-nilai Pancasila (Siregar \& Naelofaria, 2020).

Walau komunikasi dilakukan secara virtual, penulis berusaha untuk membuat nuansa pembelajaran yang menyenangkan bagi mahasiswa, dengan catatan tidak melupakan materi pokok pembelajaran. Untuk itu, tulisan ini menyampaikan beberapa rumusan di antaranya: 1) bagaimana dampak pandemi covid terhadap pendidikan tinggi? 2) Bagaimana dosen memberikan layanan pendidikan? 3) bagaimana ketercapaian tujuan pembelajaran pendidikan Pancasila?

\section{Metode}

Penelitian artikel ini dilakukan melalui pendekatan deskriptif - kualitatif. Data primer dari observasi selama pembelajaran, atau dengan kata lain menitik beratkan pada pengalaman selama proses pembelajaran yang dilakukan dalam perkuliahan Pendidikan Pancasila. Data sekunder dari berbagai literatur yakni hasil penelitian dan kajian yang relevan yang telah menjadi jurnal, artikel, prosiding, dan lain-lain. Penelitian dilaksanakan di berbagai Jurusan di Universitas Siliwangi di antaranya Jurusan Gizi, Kesehatan Masyarakat, Akuntansi, serta Keuangan dan Perbankan. Jurusanjurusan tersebut merupakan tempat dimana penulis mengampu mata kuliah Pendidikan Pancasila semester ganjil 2020/2021. Waktu penelitian dimulai dari Oktober 2020 sampai dengan Januari 2021. Semua data-data dikumpulkan sesuai dengan rumusan masalah penelitian kemudian dilakukan reduksi data, penyajian data dan verifikasi data.

\section{Hasil dan Pembahasan}

Hal pertama dari adanya pandemi ini bagaimana respon pemerintah dalam bidang pendidikan agar proses pembelajaran tidak terhambat. Berdasarkan laporan Viva News 17 Maret 2020, Pemerintah Provinsi di seluruh wilayah Indonesia sepakat menutup sekolah maupun universitas mulai tanggal 16 Maret 2020. Hal tersebut membuat pemerintah Indonesia berpikir keras untuk mencari solusi agar pendidikan di Indonesia tidak terhambat karena adanya pandemi ini (Karlina et al., 2020, hal. 121). Untuk mengatasi masalah pendidikan, maka Menteri Pendidikan dan Kebudayaan (Mendikbud), Nadiem Anwar Makarim, menerbitkan Surat Edaran Nomor 4 Tahun 2020 tentang pelaksanaan pendidikan dalam masa darurat Covid-19. Alhasil, demi upaya mencegah penyebaran dan penularan virus tersebut, maka pembelajaran dilakukan secara daring sistem aplikasi seperti: whatsapp group, telegram group, google classroom, zoom meet, cisco webex dan sistem aplikasi online lainnya mulai dipergunakan dari tingkat sekolah dasar hingga perguruan tinggi. Selama ini, sistem pembelajaran biasanya dilakukan secara tatap muka langsung antara pendidik dengan peserta didik. Namun, dengan kondisi pandemi Covid-19, ada sebuah tantangan baru bagi dunia pendidikan. Tantangan tersebut tetap bermuara dari sistem pembelajaran yang seketika berubah menjadi sistem pembelajaran daring (Siregar \& Naelofaria, 2020, hal. 130).

Keputusan tersebut merupakan acuan bagi pada pendidik termasuk dosen untuk melakukan berbagai upaya pembelajaran yang dilakukan dalam jarak jauh sehingga menuntut penggunaan media online sebagai sarana pembelajaran. Kebijakan tersebut juga diperkuat oleh surat edaran no 15 tahun 2020 tentang pedoman penyelenggaraan belajar dari rumah dalam masa darurat penyebaran corona virus disease (covid-19) yang tujuannya adalah memastikan pemenuhan hak anak untuk mendapatkan layanan pendidikan selama darurat Covid-19, dan mencegah serta melindungi warga satuan pendidikan dari dampak Covid-19 tersebut. Konsep belajar dari rumah ini direalisasikan dengan istilah belajar moda daring yang memungkinkan tetap adanya interaksi antara guru dan siswa dalam proses pembelajaran. Pembelajaran daring menggunakan kemajuan teknologi informasi dan akses internet (Santika, 2020, hal. 12). 
Namun, dari hasil kajian kebijakan pemerintah dalam bidang pendidikan masih belum efektif dilakukan. Hal tersebut dikarenakan masih banyak kendala yang dihadapi mahasiswa yaitu dialami oleh mayoritas responden $(70,1 \%)$. Kendala yang dihadapi salah satunya adalah masalah koneksi jaringan sehingga tidak jarang mahasiswa hadir terlambat untuk mengikuti pembelajaran online. Sebanyak $18,4 \%$ responden menyatakan bahwa mereka sering terlambat mengikuti pembelajaran online karena masalah jaringan. Hal yang menarik adalah terdapat $73,6 \%$ responden yang menyatakan dapat mengatasi permasalahan yang timbul. Berkenaan dengan penerapan nilai-nilai Pancasila, kondisi di atas terkait dengan sila kedua, yaitu Kemanusiaan yang Adil dan Beradab. Kedisiplinan dalam mengikuti pembelajaran dari rumah merupakan salah satu bentuk ketaatan terhadap nilai-nilai Pancasila. Mahasiswa diharapkan dapat secara mandiri mengelola waktu belajarnya sesuai jadwal yang dikelola oleh program studinya (Karlina et al., 2020).

Sebagai salah seorang dosen, penulis berupaya untuk menjalankan apa yang menjadi anjuran kementerian pendidikan dan kebudayaan agar di tengah pandemi ini tetap berjalan dengan baik. Berdasarkan hasil penelitian Napitupulu (2020, hal. 30-31) diketahui bahwa secara keseluruhan baik dari sisi teknologi maupun sisi dosen, mahasiswa merasa tidak puas. Mahasiswa tidak puas dengan metode PJJ yang dijalaninya saat ini dan juga merasa tidak puas dengan kemampuan Dosen dalam menyampaikan materi pada PJJ. Berdasarkan hasil penelitian tersebut, maka perguruan tinggi perlu meninjau kembali metode PJJ yang ada saat ini. Selain itu juga perlu memperkuat kemampuan literasi digital baik mahasiswa maupun dosen. Ketidakpuasaan sebagaimana hasil penelitian tersebut merupakan salah satu yang menjadi alasan penulis untuk melakukan improvisasi pembelajaran pada mata kuliah Pendidikan Pancasila sebagaimana yang diampu. Sehingga selalu berupaya untuk memperbaiki yang menjadi kelemahan dasar di antaranya pemilihan media pembelajaran, teknik penyampaian materi, teknik evaluasi pembelajaran, gaya mengajar, cara berkomunikasi dengan mahasiswa, dan lain-lain.

Kondisi pendidikan yang tidak diharapkan menantang dosen untuk melakukan berbagai upaya layanan yang baik. Agar pelayanan dapat memuaskan Mahasiswa, maka pegawai yang bertugas melayani harus memenuhi empat kriteria pokok menurut (Moenir, 2010) yaitu: 1) tingkah laku yang sopan; 2) cara menyampaikan sesuatu yang berkaitan dengan apa yang seharusnya; 3) diterima oleh orang yang bersangkutan; 4) waktu menyampaikan yang tepat; 5) keramah tamahan (Rahardjo, 2018, hal. 101).

Mata Kuliah Pendidikan Pancasila yang merupakan materi pokok di semua program studi, selama ini banyak dikeluhkan oleh mahasiswa sebagai mata kuliah yang membosankan. Tanpa adanya upaya dari dosen pengampu untuk melakukan evaluasi diri, niscaya mata kuliah ini akan tetap dipandang negatif oleh berbagai pihak.

Untuk itu, dalam kuliah Pancasila juga sangat penting untuk selalu meningkatkan kualitas layanan. Kualitas pelayanan ditentukan oleh dua hal, yaitu Expected service dan Preceived service. Expected service dan Preceived service ditentukan oleh Dimention of service quality yang terdiri dari sepuluh dimensi, yaitu: tangible (terjamah), reliability (handal), responsiveness (tanggap), competence (kompeten), courtesy (ramah), credibility (dapat dipercaya), security (aman), access (akses), communication (komunikasi), understanding the customer (memahami pelanggan). Expected service (pelayanan yang diharapkan) dipengaruhi oleh word of mouth (kata yang diucapkan), personal need (kebutuhan personal), past experience (pengalaman masa lalu), dan external communication (komunikasi eksternal) (Rahardjo, 2018; Zeithaml et al., 1990).

Kualitas layanan dalam bidang pendidikan sebagaimana yang ditulis dalam artikel ini adalah bagaimana pembelajaran jarak jauh atau daring ini tidak mengurangi kualitas layanan pendidikan itu sendiri. Oleh karena itu, sangat penting bagi tenaga pendidik untuk lebih kreatif dan inovatif dalam mengemas proses pembelajaran. Menurut Moore et al., (2011), pembelajaran daring merupakan pembelajaran yang menggunakan jaringan internet dengan aksesibilitas, konektivitas, fleksibilitas, dan kemampuan untuk memunculkan berbagai jenis interaksi pembelajaran. Saat ini program $e-$ learning sedang menjadi perbincangan hangat di dunia pendidikan, seiring bertambah canggihnya teknologi mempengaruhi metode pembelajaran dan semakin canggih. sistem e-learning terdiri dari empat komponen, terutama; instruktur, pelajar, kursus, dan teknologi informasi dan komunikasi (TIK) (Romi, 2017). Penelitian yang dikakukan oleh Zhang et al., (2004) menunjukkan bahwa 
penggunaan internet dan teknologi multimedia mampu merombak cara penyampaian pengetahuan dan dapat menjadi alternatif pembelajaran yang dilaksanakan dalam kelas tradisional.

Pelaksanaan pembelajaran mata kuliah Pancasila di era pandemi covid 19 ini dilakukan dengan memanfaatkan media pembelajaran. Langkah yang dilakukan dengan mengemas materi kuliah pendidikan Pancasila dengan 3 media, yakni Google Classroom, Youtube dan Zooom. Pertama, menggunakan google classroom (Gambar 1). Media ini sangat mudah untuk mengumpulkan mahasiwa setiap kelas dengan menyampaikan materi-materi atau bahan ajar, penugasan setiap bab, absen kelas, maupun melalukan berbagai upaya lain. Namun, penulis lebih memilih zoom dibanding dengan google meet yang sudah langsung tersedia di google classroom. Mahasiswa harus lebih sering membuka google classroom tanpa harus menunggu jadwal kuliah, hal itu penting karena dosen memberikan berbagai informasi penting seputar perkuliahan. Namun, kelemahan dari media ini juga tidak semua aspek perkuliahan dapat dilakukan di google classroom ini sehingga dibantu oleh media online yang lainnya.

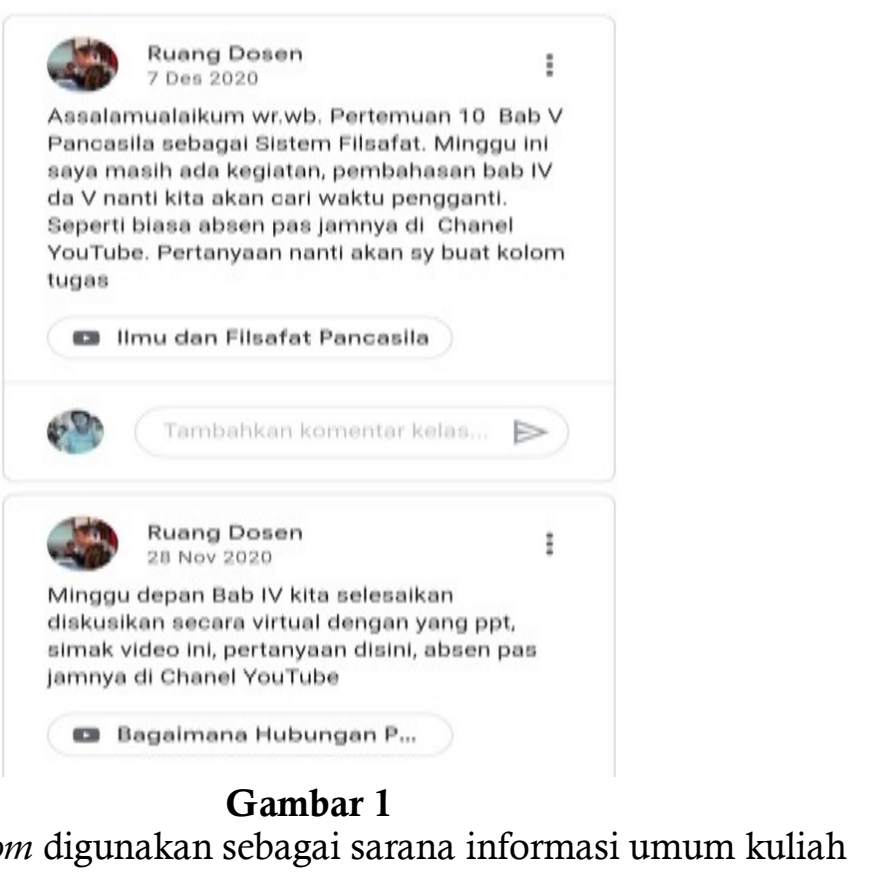

Kedua, menampilkan dan merekam video di youtube (Gambar 2). Setiap materi, dosen merekam video yang variatif sesuai tema atau materi kuliah, kemudian di opload di youtube. Rata-rata seminggu sebelum jadwal materi tersebut, dosen sudah meng-opload video di channel youtube untuk disimak oleh mahasiswa sebagai materi pokok perkuliahan. Setelah mahasiswa menyimak materi kemudian membuat pertanyaan di forum google classroom dan dibahas ketika jadwal kuliah.

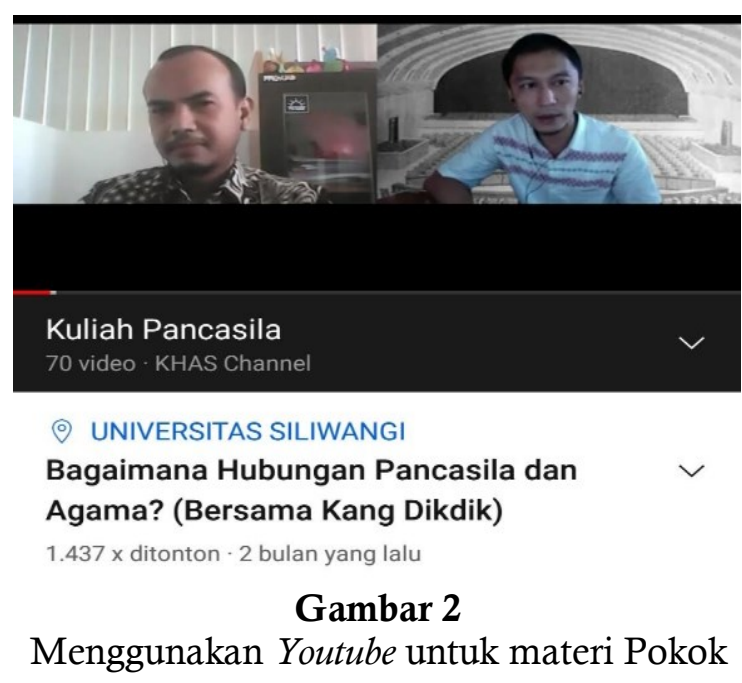


Selama proses pembelajaran yang dilakukan setiap minggu melalui berbagai media pembelajaran online, penulis selalu melalukan berbagai evaluasi. Berusaha untuk tidak monoton dalam menyampaikan materi, sesekali mahasiswa juga menyampaikan berbagai keluhan walaupun keluhan akhir dilakukan dalam evaluasi yang lebih menyeluruh dalam pertemuan terakhir. Ide-ide penyampaian materi yang diunggah ke youtube, kontennya tidak sama karena menyesuaikan dengan materi-materi kuliah yang setiap pertemuan berbeda. Dosen tidak hanya berbicara sendiri, adakalanya mengundang dosen lain untuk menjadi pembicara sesuai tema, misalnya dalam kajian sejarah mengundang dosen sejarah, dalam materi ideologi dan agama mengundang dosen dari luar yang kompeten dibidang ilmu agama dan kepancasilaan.

Ketiga, membahas materi di zoom (Gambar 3) setelah mahasiswa menyimak dan memberikan pertanyaan di materi youtube. Pembahasan di zoom juga direkam untuk diupload lagi di channel youtube. Cara ini cukup membantu mahasiswa yang belum paham penjelasan langsung di zoom dapat melihat pembahasan ulangnya di youtube.

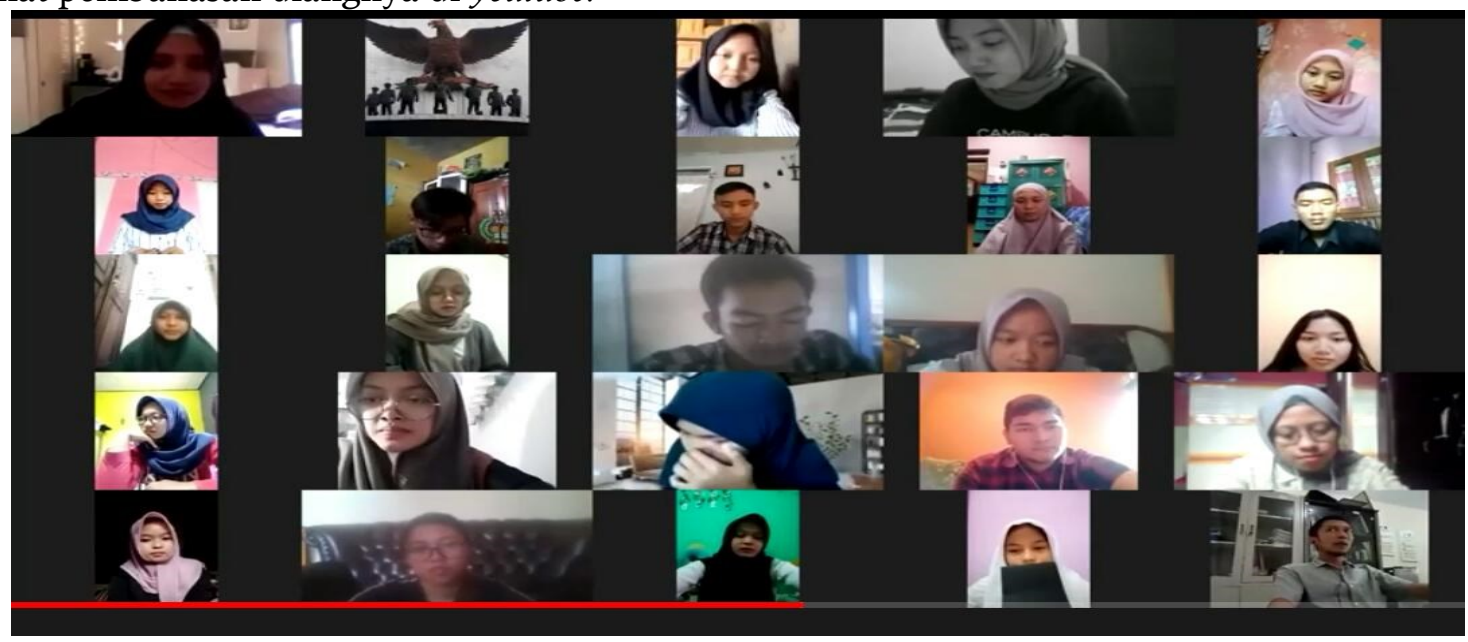

Gambar 3

Pembahasan Materi di Zoom

Penggunaan media pembelajaran tersebut juga tidak hanya berpusat pada dosen, atau teacher centre, tetapi juga melibatkan mahasiswa untuk aktif termasuk dalam mengevaluasi pembelajaran daring yang dilakukan oleh dosen. Mahasiswa membuat video kelompok dimana setiap individu wajib memberikan presentasi bab akhir serta melalukan evaluasi pembelajaran yang telah dilakukan.

Hal yang cukup berat selama proses ini adalah bagaimana pembentukan karakter kebangsaan yang tujuan utama kuliah Pendidikan Pancasila, sementara perkuliahan tanpa tetap muka langsung. Penulis selalu berupaya agar pembelajaran daring ini tetap tidak menghilangkan mutu pendidikan. Mutu pembelajaran online atau e-learning dapat dilihat dari beberapa kategori yaitu; 1) keistimewaan, 2) kesempurnaan atau konsistensi, 3) kesesuaian dengan tujuan, dan 4) transformasi. Kategori transformasi merupakan hal yang paling relevan dari proses pembelajaran. Transformasi menggambarkan peningkatan kompetensi sebagai hasil dari proses pembelajaran. Terdapat pendapat lain yang menyatakan beberapa faktor yang mempengaruhi efektivitas sebuah elearning antara lain; (1) interaksi, (2) kerja sama, (3) motivasi, (4) networking, (5) pedagogi. (Prasetya \& Harjanto, 2020, hal.189-190). Saat ini program e-learning sedang menjadi perbincangan hangat di dunia pendidikan, seiring bertambah canggihnya teknologi mempengaruhi metode pembelajaran dan semakin canggih. sistem e-learning terdiri dari empat komponen, terutama; instruktur, pelajar, kursus, dan teknologi informasi dan komunikasi (TIK) (Romi, 2017). Untuk beralih dari model pembelajaran tatap muka atau bertemu secara langsung, lalu berubah menjadi daring (online) itu sangat membutuhkan effort dan biaya yang tidak sedikit. E-learning sebagai teknologi menjadi lebih terjangkau dalam pendidikan tinggi tetapi memiliki hambatan besar dalam biaya pengembangan sumber dayanya (Muniasamy et al., 2020). Pembelajaran dengan menggunakan kecerdasan buatan terus menjadi semakin populer dan berdampak pada banyak bidang e-learning

Manfaat dari penggunaan e-learning dan juga blended learning dalam dunia pendidikan saat ini adalahe-learning memberikan fleksibilitas dalam memilih waktu dan tempat untuk mengakses 
pelajaran (Márquez \& Jiménez-Rodrigo, 2014; Trujillo Maza et al., 2016). Mahasiswa tidak perlu mengadakan perjalanan menuju tempat pelajaran disampaikan, e-learning bisa dilakukan dari mana saja baik yang memiliki akses ke Internet ataupun tidak.

Mata kuliah Pendidikan Pancasila yang diajarkan di semua program studi, secara normatif memang tidak hanya membicarakan indoktrinasi penanaman nilai-nilai kebangsaan. Ada materi pokok yang merupakan integrasi Pancasila dengan ilmu pengetahuan dan teknologi. Pada materi inilah dosen memberikan kebebasan kepada mahasiswa untuk mengembangkan disiplin ilmu yang sesuai dengan program studinya dikaitkan dengan Pancasila. Pancasila sebagai landasan pengembangan ilmu ini sangat menarik mahasiswa untuk lebih memahami Pancasila karena berhubungan juga dengan ilmu yang secara spesifik mereka pelajari di jurusan atau program studi masing-masing.

Berbagai upaya yang dilakukan oleh penulis sudah cukup efektif walau terkadang ada beberapa kendala teknis yang mungkin bisa diatasi oleh dosen. Pendidik sudah cukup berupaya dalam mencapai tujuan Pendidikan Pancasila. Namun ada beberapa kendala dalam pembelajaran online ini seperti yang disebutkan yakni mahasiswa dalam perkuliahan daring di antaranya adalah ketersediaan paket data, HP, laptop dan jaringan internet yang mendukung. Faktor yang menjadi penghambat dalam proses perkuliahan daring adalah kurangnya paket data dan internet. Sehingga mahasiswa lebih memilih perkuliahan dengan tatap muka dibandingkan dengan perkuliahan online karena interaksi antar dosen dan mahasiswa dapat dilakukan dalam ruangan kelas dan tidak membutuhkan aplikasi (Lande, 2020).

Penulis sangat menitikberatkan pada proses pembelajaran online ini pada tujuan pendidikan Pancasila sebagai pendidikan karakter kebangsaan. Pendidikan saat ini telah memasuki awal disrupsi pendidikan, kebijakan yang mendadak itu membuat kesulitan bagi guru khususnya guru PPKn dalam mengelola kelas. Sehingga perlu peningkatan kompetensi guru PPKn dalam pembelajaran daring. Penilaian kompetensi peserta didik yang belajar Pendidikan Pancasila dan Kewarganegaraan secara umum dapat dikatakan berfungsi untuk melayani peningkatan akuntabilitas dan kualitas sarana prasarana lembaga pendidikan, dan proses pengajaran serta pembelajaran berorientasi perkembangan siswa sebagai subjek pembelajaran tentunya (Juwandi, 2020).

Pendidikan kalau hanya di artikan sebagai pembelajaran atau transfer pengetahuan (knowledge) saja mungkin itu relatif mudah. Penggunaan media pembelajaran dengan menyampaikan meteri secara daring bisa saja tercapai. Hal yang cukup berat adalah memaknai pendidikan sebagai transfer nilai (value) sebagai mana dalam pendidikan Pancasila sebagai salah satu pendidikan karakter kebangsaan.

Integrasi pendidikan yang bermuatan karakter dalam era daring ini dapat dilihat dari pendidikan karakter sebagai fungsi pembentukan dan pengembangan potensi. Pendidikan karakter membentuk dan mengembangkan potensi agar berpikiran baik, berhati baik, dan berperilaku sesuai dengan falsafah Pancasila. Pendidikan karakter memperbaiki dan memperkuat peran keluarga, satuan pendidikan, masyarakat, dan pemerintah untuk ikut berpartisipasi dan bertanggung jawab dalam pengembangan potensi warga negara dan pembangunan bangsa menuju bangsa yang maju, mandiri, dan sejahtera. Pendidikan karakter memilah budaya bangsa sendiri dan menyaring budaya bangsa lain yang tidak sesuai dengan nilai-nilai budaya bangsa dan karakter bangsa yang bermartabat. Pembelajaran tanpa tatap muka secara langsung, tetapi dilakukan melalui jaringan internet (online) dari tempat yang berbeda-beda, diperlukan prinsip strategi Multiple Intelligences pada pendidikan karakter masih menggunakan prinsip pendekatan pembelajaran kontruktivistik. Peserta didik secara aktif mengembangkan kedelapan potensi yang dimiliki disesuaikan dengan kompetensi dasar yang diajarkan dan bagaimana aktualisasinya terutama jika ada kaitan dalam menghadapi Covid-19. Strategi implementasi pendidikan karakter melalui multiple intelligences berbasis portofolio dengan diintegrasikan pada mata pelajaran merupakan suatu upaya dalam proses pembelajaran untuk dapat mengembangkan life skill atau kecakapan peserta didik (Santika, 2020, hal. 16).

Dari uraian di atas dapat diketahui bahwa pembelajaran Pendidikan Pancasila sebagai pendidikan karakter kebangsaan Indonesia sangat penting untuk tetap dilaksanakan dengan menyentuh aspek-aspek nilai kepribadian mahasiswa. Materi ini memang harus secara dalam hati dan pikirannya karena merekalah yang akan menjadi penerus bangsa di masa yang akan datang. 
Apalagi pada jenjang pendidikan tinggi, para mahasiswa harus tetap diperhatikan perilakunya selama perkuliahan oleh dosen walaupun pada saat ini perkuliahan dilaksanakan melalui media online.

\section{Simpulan}

Hasil penelitian ini dapat disimpulkan bahwa Improvisasi Pembelajaran Pendidikan Pancasila pada Era Pandemi Covid-19 dilakukan melalui media pembelajaran dalam jaringan. Melakukan berbagai upaya peningkatan layanan pendidikan yang baik di antaranya dengan memilih media pembelajaran dapat mempermudah komunikasi dosen dengan mahasiswa, serta melakukan cara-cara yang kreatif dan inovatif selama proses pembelajaran online. Improvisasi bukan berarti mengabaikan esensi, karena dilakukan dengan persiapan yang baik, improvisasi yang dimaksud lebih kepada melihat situasi pada saat proses berlangsung sehingga dapat memperbaiki hal-hal yang kurang baik pada saat itu maupun untuk pertemuan berikutnya. Secara khusus hasil penelitian dapat diketahui bahwa: pertama, dampak pandemi covid 19 terhadap Pendidikan Tinggi memaksa pemerintah untuk mengeluarkan regulasi dalam mengatasi pendidikan di tengah virus corona yang semakin menyebar. Kementerian Pendidikan dan Kebudayaan pada akhirnya mengeluarkan edaran sebagai payung hukum para pendidik melaksanakan pendidikan dalam jaringan (daring). Kedua, kualitas dosen dalam memberikan layanan pendidikan memang belum banyak memuaskan mahasiswa dalam pembelajaran daring ini. Pada mata kuliah Pendidikan Pancasila saja misalnya yang dalam kondisi normal saja banyak yang tidak menyukai, ditengah pandemi ini cukup memberikan tantangan bagi para dosen untuk senantiasa mengevaluasi diri agar materi kuliah tetap mudah dicerna mahasiswa. Ketiga, ketercapaian tujuan pembelajaran Pendidikan Pancasila melalui media online ini masih banyak yang harus diperbaiki. Penggunaan berbagai media yang terkadang tidak semua mahasiswa dapat mengakses itu merupakan masalah terbesar. Namun, melalui cara yang lebih humanis apa pun media komunikasinya, memperlakukan dan tetap melayani mahasiswa dengan baik serta lebih menyentuh hati dan pikiran mahasiswa, itu yang perlahan akan menyadarkan mahasiswa sebagai generasi bangsa yang akan menanamkan serta mengamalkan nilai-nilai Pancasila sepanjang hayat.

\section{Ucapan Terima Kasih}

Dalam proses pembuatan tulisan ini yang diambil dari pengamalan penulis selama melakukan perkuliahan pendidikan Pancasila di era pandemi covid ini tidak hanya melakukan kegiatan sendiri. Ada beberapa pihak yang terlibat khususnya yang menjadi narasumber setiap materi perkuliahan. Hal ini dimaksudkan untuk menambah wawasan mahasiswa terkait materi kuliah, juga sebagai salah satu upaya kreativitas dosen untuk membuat konten-konten pembelajaran yang lebih variatif. Penulis sangat berterima kasih kepada sesama dosen dari Universitas Siliwangi yang manjadi narasumber yakni H. Nana Setialaksana, M.Pd., Randy Fadillah, M. Pd., Zulpi Miftahudin, M.Pd., dan Iwan Ridwan, S.H.,M.H. Selain itu juga kepada Bapak Dikdik Baehaqi Arief, S. Pd., M. Pd sebagai narasumber dari luar Universitas Siliwangi karena beliau merupakan Ketua Program Studi PPKn dari Universitas Ahmad Dahlan Yogyakarta yang telah banyak memberikan masukan dan menambah wawasan mahasiswa tentang hubungan Agama (Islam) dan Pancasila.

\section{Referensi}

Juwandi, R. (2020). Penguatan pendidikan pancasila dan kewarganegaraan berbasis pembelajaran daring di era digital 4.0. In Prosiding Seminar Nasional Pendidikan FKIP (Vol. 3, Nomor 1, hal. 448-451). Universitas Sultan Ageng Tirtayasa. https://jurnal.untirta.ac.id/index.php/psnp/article/view/9972

Karlina, S., Nurfaridah, W. O., Lasambouw, C. M., \& Mathilda, F. (2020). Penerapan nilai-nilai Pancasila di kalangan mahasiswa dalam melaksanakan kebijakan pemerintah dalam bidang pendidikan di era pandemi Covid-19. The 11th Industrial Research Workshop and National Seminar, 26-27.

Lande, A. (2020). Persepsi mahasiswa Pendidikan Kewarganegaran Universitas Tadulako terhadap perkuliahan online di masa pandemi Covid 19. Jurpis: Jurnal Pendidikan Ilmu Sosial, 17(2), 209- 
226.

Márquez, E., \& Jiménez-Rodrigo, M. L. (2014). Project-based learning in virtual environments: a case study of a university teaching experience. Revista de Universidad y Sociedad del Conocimiento (RUSC), 11(1), 76-90. https://doi.org/http://dx.doi.org/10.7238/rusc.v11i1.1762

Moenir, A. S. (2010). Manajemen pelayanan umum di Indonesia. Bumi Aksara Jakarta.

Moore, J. L., Dickson-Deane, C., \& Galyen, K. (2011). E-Learning, online learning, and distance learning environments: Are they the same? The Internet and Higher Education, 14(2), 129-135. https://doi.org/10.1016/j.iheduc.2010.10.001

Muniasamy, A., Alasiry, A., \& Arabia, S. (2020). Deep Learning : the impact on future e-learning. International Journal of Emerging Technologies in Learning, 15(1), 188-199. https://doi.org/https://doi.org/10.3991/ijet.v15i01.11435 Anandhavalli

Napitupulu, R. M. (2020). Dampak pandemi Covid-19 terhadap kepuasan pembelajaran jarak jauh. Jurnal Inovasi Teknologi Pendidikan, 7(1), 23-33. https://doi.org/10.21831/jitp.v7i1.32771

Rahardjo, D. (2018). Kajian kepuasan mahasiswa terhadap layanan proses pembelajaran jarak jauh pada Program Studi D2 Perpustakaan. Jurnal Pendidikan Terbuka dan Jarak Jauh, 19(2), 99-118.

Romi, I. M. (2017). A model for e-learning systems succss: systems, determinants, and performance. International Journal of Emerging Technologies in Learning, 12(10), 4-20. https://doi.org/10.3991/ijet.v12i10.6680

Santika, I. W. E. (2020). Pendidikan karakter pada pembelajaran daring. IVCEJ, 3(1), 8-19. https://ejournal.undiksha.ac.id/index.php/IVCEJ/article/view/27830

Siregar, I., \& Naelofaria, S. (2020). Internalisasi nilai-nilai pancasila dalam pembelajaran dalam jaringan (daring) tingkat sekolah dasar (SD) di era pandemi covid-19. Jurnal Pendidikan Sosial Keberagaman, 7(2), 130-135.

Sumarwoto. (2020). Strategi pembelajaran mata kuliah Pancasila Dan Kewarganegaraan secara daring melintasi masa pandemi Covid-19. WAHANA PEDAGOGIKA, 2(2), 109-116.

Trujillo Maza, E. M., Gómez Lozano, M. T., Cardozo Alarcón, A. C., Moreno Zuluaga, L., \& Gamba Fadul, M. (2016). Blended learning supported by digital technology and competencybased medical education: a case study of the social medicine course at the Universidad de los Andes, Colombia. International Journal of Educational Technology in Higher Education, 13(1). https://doi.org/10.1186/s41239-016-0027-9

Zeithaml, V. A., Parasuraman, A., \& Berry, L. L. (1990). Delivering quality service: Balancing customer perceptions and expectations. Simon and Schuster.

Zhang, D., Zhao, J. L., Zhou, L., \& Nunamaker, J. F. (2004). Can e-learning replace classroom learning? In Communications of the ACM (Vol. 47, Nomor 5, hal. 75-79). ACM PUB27 New York, NY, USA. https://doi.org/10.1145/986213.986216. 